\title{
It is all in the sputum: a case of non-resolving pneumonia
}

\author{
Leanne Hanrahan, ${ }_{1}^{1}$ Sanjay Haresh Chotirmall, ${ }^{1}$ Siobhan Nicholson, ${ }^{2}$ \\ Deidre O'Riordan ${ }^{1}$
}

${ }^{1}$ Department of Internal Medicine, St James's Hospital, Dublin, Ireland

2Department of

Histopathology, St James Hospital, Dublin, Ireland

\section{Correspondence to}

Dr Sanjay Haresh Chotirmall, schotirmall@rcsi.ie

Accepted 23 October 2014
CrossMark

\section{To cite: Hanrahan $\mathrm{L}$,} Chotirmall SH, Nicholson $\mathrm{S}$, et al. BMJ Case Rep Published online: [please include Day Month Year] doi:10.1136/bcr-2014207843

\section{DESCRIPTION}

An 87-year-old woman presented with a 2-day history of dyspnoea, productive cough and rightsided chest discomfort. Having become increasingly lethargic over the preceding fortnight, she also noted unquantifiable weight loss over the prior 3-month period. Physical examination and initial
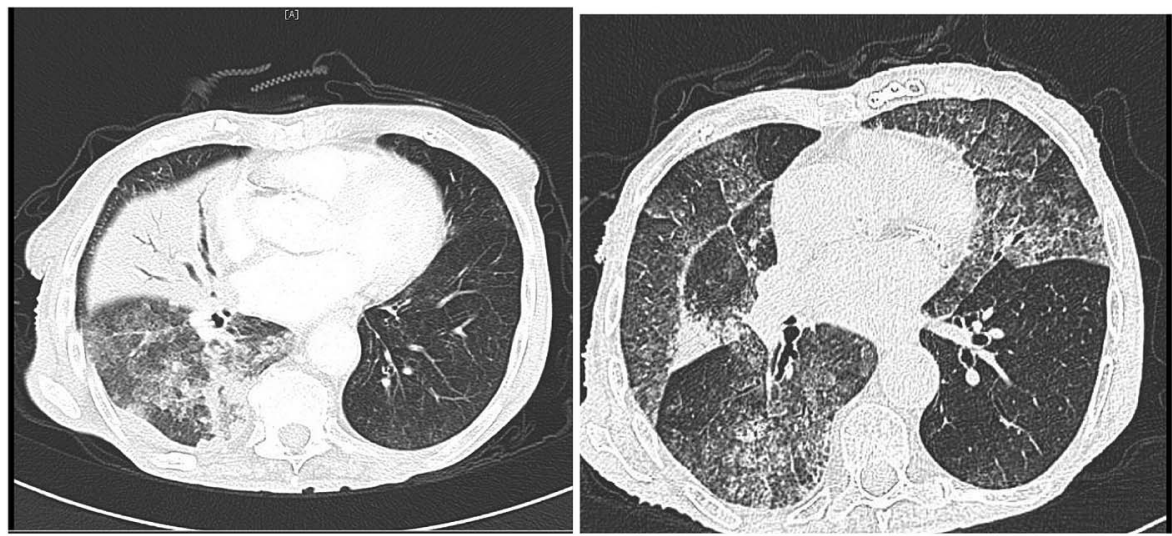

Figure 1 Dense consolidation of right middle and right lower lobes with progression of patchy ground glass infiltrates in the right upper lobes and the left base.

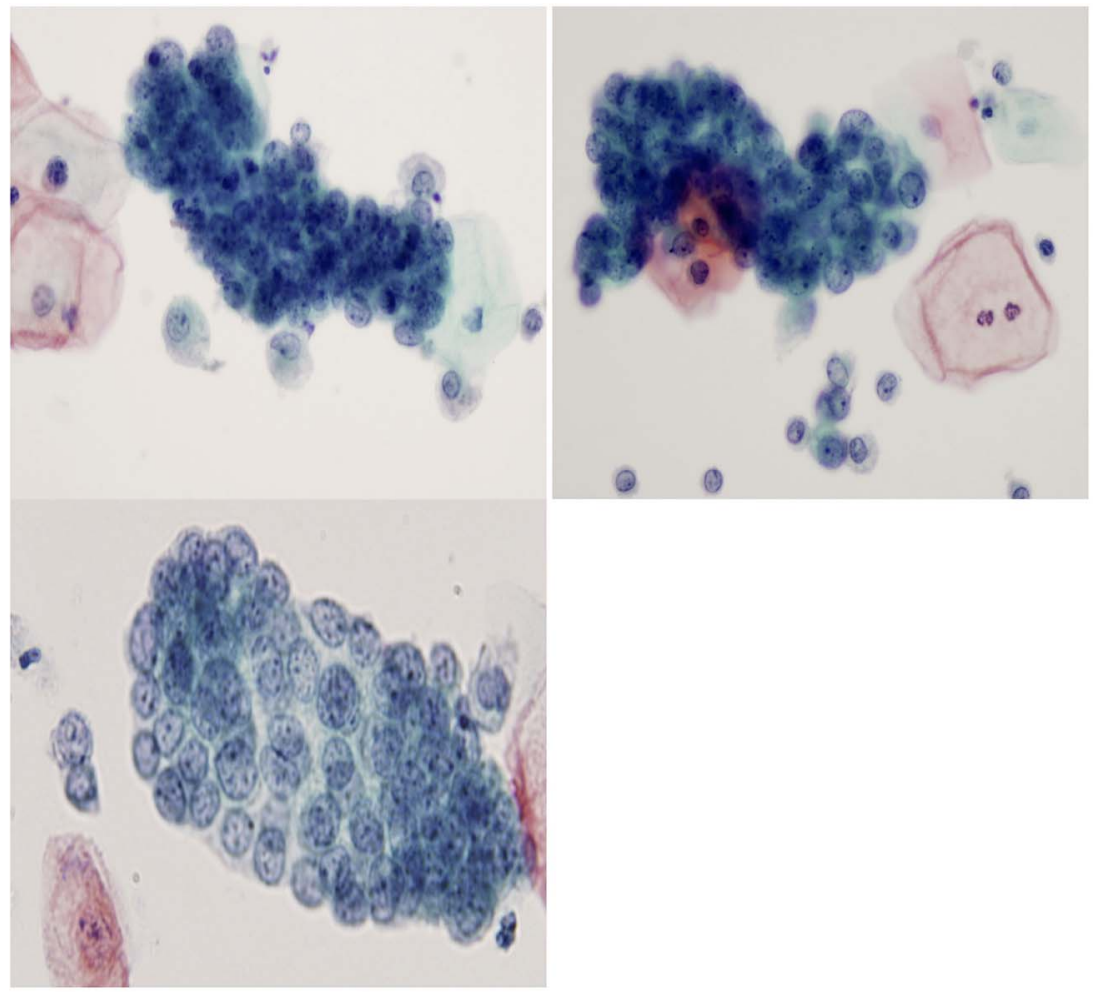

Figure 2 Malignant sputum cytology: papillary-shaped cell clusters confirm the presence of malignant tumour cells (adenocarcinoma). Also seen are squamous cells (pink) from the oral cavity and alveolar macrophages (green) that confirm that the sample originates from the lower respiratory tract. 


\section{Learning points}

- Adenocarcinoma, lepidic pattern (formerly known as bronchoalveolar carcinoma (BAC) is a subset of adenocarcinoma that has a variable clinical presentation ranging from solitary or multiple nodules to diffuse parenchymal infiltrates that can mimic a bacterial pneumonia.

- Sputum cytology can sometimes be diagnostic for malignancy, and is a simple non-invasive initial test in very frail and elderly patients and in those who are high risk for bronchoscopy.

- Bronchorrhoea is an important symptom in patients with mucinous BAC that can be treated with epidermal growth factor receptor (EGFR) tyrosine kinase (TK) inhibition corticosteroids and macrolides ${ }^{3}$ to decrease its associated inflammation.

- There are a number of molecular abnormalities that vary between mucinous and non-mucinous forms of adenocarcinoma. This has implications in terms of treatment of disease. Mutations in EGFR TK are common in non-mucinous $B A C$ and respond to tyrosine kinase inhibitors (TKIs). Mucinous adenocarcinoma tends to have mutations in the K-Ras oncogene and do not respond to TKIs. and associated specimens were sent for microbiology. Despite further escalation of antibiotic therapy, limited clinical improvement resulted. Further CT evaluation revealed persistent dense consolidation and progression of ground glass infiltrates (figure 1). With diminishing infective symptoms, a steroid trial was started for possible cryptogenic organising pneumonia. Some limited initial clinical improvement was noted followed by further deterioration with cough and bronchorrhoea. Sputum was sent for further evaluation revealing a well-differentiated adenocarcinoma $^{1}{ }^{2}$ (lepidic pattern; figure 2). The patient opted for a palliative approach to management.

Contributors $\mathrm{LH}$, SHC, SN and DO all contributed to drafting and editing the manuscript and in the clinical care of the patient.

Competing interests None.

Patient consent Obtained.

Provenance and peer review Not commissioned; externally peer reviewed.

\section{REFERENCES}

1 Travis WD, Brambilla E, Muller-Hermelink HK, et al. Pathology and genetics of tumours of the lung, pleura, thymus and heart. Lyon: IARC Press, Oxford University Press, 2004.

2 Garfield DH, Cadranel J, West HL. Bronchioloalveolar carcinoma: the case for two diseases. Clin Lung Cancer 2008;9:24.

3 Marom ZM, Goswami SK. Respiratory mucus hypersecretion (bronchorrhea): a case discussion-possible mechanisms(s) and treatment. J Allergy Clin Immunol 1991;87:1050.

Copyright 2014 BMJ Publishing Group. All rights reserved. For permission to reuse any of this content visit http://group.bmj.com/group/rights-licensing/permissions.

BMJ Case Report Fellows may re-use this article for personal use and teaching without any further permission.

Become a Fellow of BMJ Case Reports today and you can:

- Submit as many cases as you like

- Enjoy fast sympathetic peer review and rapid publication of accepted articles

- Access all the published articles

- Re-use any of the published material for personal use and teaching without further permission

For information on Institutional Fellowships contact consortiasales@bmjgroup.com

Visit casereports.bmj.com for more articles like this and to become a Fellow 